\title{
Studies of Bainitic Steel for Rail Applications Based on Carbide-Free, Low-Alloy Steel
}

\author{
BOGUSŁAWA ADAMCZYK-CIEŚLAK, MILENA KORALNIK, ROMAN KUZIAK, \\ KAMIL MAJCHROWICZ, and JAROSŁAW MIZERA
}

This paper describes the development and characterisation of bainitic steel for rail applications based on carbide-free, low-alloy steel. The results show that after rolling and subsequently cooling, the designed carbide-free bainitic steel exhibits better mechanical performance than standard pearlitic steel. This is because of its fine, carbide-free bainitic microstructure, which consists of bainitic ferrite and retained austenite laths. Microstructural and mechanical property analysis was carried out using scanning and transmission electron microscopy, X-ray diffraction, hardness measurements, tensile and low-cycle fatigue tests. The obtained results demonstrate that during low cyclic deformation, a partial transformation of the retained austenite into deformed martensite $\alpha^{\prime}$ takes place, and strain-induced martensitic transformation occurs. The initial strengthening of the material during low-cycle fatigue was caused by the transformation of austenite into martensite and the increase in the dislocation density of the steel. In addition, an optimal amount of retained austenite in the form of thin layers and islands (dimensions not exceeding $1 \mu \mathrm{m}$ ) made it possible to obtain a high yield while maintaining the high plasticity of the steel. These microstructural features also contributed to the high crack resistance of the tested carbide-free bainitic steel.

https://doi.org/10.1007/s11661-021-06480-6

(C) The Author(s) 2021

\section{INTRODUCTION}

SOME of the most popular and widely used types of rail steel are pearlitic carbon-manganese steels. These materials (e.g. R260 grade or carbon-manganese steels used for the production of heat-treated materials) develop moderate strength after rolling, followed by continuous cooling without heat treatment. ${ }^{[1]}$ However, harder steels (e.g. R350HT) are used in certain rail locations, such as turnouts or bends with radii up to 800 $\mathrm{m}$, because these sections of rail typically wear out more intensively during service. For turnouts and rail crossings that are most subject to wear and damage as a result of cracking, Hadfield steel is used to produce the most wear-resistant and durable structures. ${ }^{[2]}$ When designing new steels for railway solutions, attention should also be paid to the rate at which contact - fatigue phenomena occur. In cases where materials with lower hardness are applied, continuous and more intensive

BOGUSŁAWA ADAMCZYK-CIEŚLAK, MILENA KORALNIK, KAMIL MAJCHROWICZ, and JAROSŁAW MIZERA are with the Faculty of Materials Science and Engineering, Warsaw University of Technology, Warsaw, Poland. Contact e-mail: milena.koralnik@pw. edu.pl; boguslawa.cieslak@pw.edu.pl ROMAN KUZIAK is with the Lukasiewicz Research Network - Institute for Ferrous Metallurgy, Gliwice, Poland.

Manuscript submitted June 7, 2021, accepted September 28, 2021. Article published online October 22, 2021 abrasion of the surface layer is possible, resulting in micro-crack removal. However, this phenomenon can cause excessive and rapid tribological wear of the rails. The initiation of micro-cracks on a rail surface is inhibited for high hardness steels, although the limited wear may increase their propagation rate. One potential solution that mitigates most of the problems inherent to the pearlitic steel structure is to use bainitic steels. It was found that the microstructure of the degenerated upper bainite with retained austenite (RA), present in the form of layers between bainitic ferrite (BF) laths, gives the best relationship between strength and ductility. ${ }^{[3,4]}$ However, the use of traditional bainitic steels in rails solutions is severely limited due to the presence of carbide particles at lath boundaries of bainitic ferrite, which contribute to an increase in rail brittleness. ${ }^{[5]}$ In lower bainite, fine dispersion cementite precipitates occur in the form of plates inside ferrite laths are arranged parallelly at the angle of 55 to $65 \mathrm{deg}$ to the lengthwise laths' axis.

Therefore, intensive research efforts have focussed on carbide-free bainitic steels, which can be obtained through appropriate modification of the chemical composition, or through optimised heat treatment and rolling processes. ${ }^{[6-8]}$ Hasan et al..$^{[9]}$ designed two new carbide-free bainitic steels with minimal alloying additions and processed to achieve high strength and toughness. The microstructure of steels consisted laths 
of bainitic ferrite and retained austenite, mainly in the form of thin films.

The desired microstructure can be achieved by incorporating an appropriate silicon content, which effectively suppresses cementite precipitation during the bainitic transformation, resulting in carbide-free microstructures composed of bainitic ferrite laths and carbon-enriched retained austenite with thin films and blocky morphologies. ${ }^{[10-12]}$ Moreover, the grain size of primary austenite decreases with an increase in silicon content. The bainitic transformation occurs at austenite grain boundaries. An increase in $\mathrm{Si}$ content in steel reduces the carbon diffusion rate from ferrite to neighbouring austenite, causing inhibition of bainite nucleation and growth. ${ }^{[13]}$ In addition, increased carbon content stabilises untransformed austenite, such that the volume fraction of this phase can reach up to 20 to 25 pct. It is also important to note the impact of carbon on the decreasing temperature value at the beginning and end of the martensitic transformation. In turn, the proper concentration of $\mathrm{Si}$ content suppresses the precipitation of brittle cementite during bainitic transformation and increases the amount of $\mathrm{BF}$ and retained austenite. The transformation of RA present in the microstructure to strain or stress-induced martensite strengthens the steel, resulting in higher ductility. ${ }^{[14]}$ These steels are characterised by excellent mechanical properties, (e.g. high hardness, tensile strength and resistance to brittle cracking), while maintaining high ductility. These unique properties result from the submicron or nanometric grain size of bainitic ferrite and the appropriate content of retained austenite (blocky as well as filmy). The carbide-free bainitic steel developed by Das et al. ${ }^{[15]}$ has about 80 pet of bainitic ferrite and 20 pct of retained austenite. This microstructure provided the ultimate tensile strength $\sim 1400 \mathrm{MPa}$ and total elongation above 20 pct. Ultra-fine $(\sim 100$ to $130 \mathrm{~nm}$ thick) BF laths with high dislocation density are responsible for ultra-high strength. A sufficient amount of RA that is thermally stable at room temperature but transforms to martensite under strain affects the excellent ductility of steel. RA can also improve wear resistance by transforming into martensite under the influence of frictional stress. ${ }^{[16]}$ This increases the material's hardness via work hardening at the contact point, which has a positive effect on abrasion resistance relative to conventionally treated pearlitic steels samples. With a properly designed chemical steel composition, austenite can be stabilised during annealing and bainitic transformation because of the increasing carbon concentration in austenite crystal lattice.

The Transformation-Induced-Plasticity (TRIP) effect in steels is the particular formation of martensite induced by plastic deformation. The microstructure of these steels includes a metastable retained austenite, bainitic ferrite and acicular ferrite. Under deformation, the RA transforms into martensite, and the mechanism is associated with energy absorption resulting in a hardening of the material. ${ }^{[17]}$ Due to the transformation effect's gradual strain hardening mechanism, these steels offer significant advantages in their mechanical behaviour (e.g. high strength and ductility). The TRIP effect also influences low-cycle fatigue (LCF) conditions, accompanied by cyclic plastic strains assisting retained austenite transformation. In numerous studies, ${ }^{[18-22]}$ it has been reported that under cyclic loading, the transformation of austenite to martensite influences the mechanical properties and fatigue behaviour of steels. There are also literature reports indicating that the cyclic strengthening or weakening phenomena in steels are not only related to the strain-induced transformation of austenite to martensite. ${ }^{[23,24]}$ Fatigue life is also dependent on the volume fraction of RA. Hu et al. ${ }^{[25]}$ described that a high level of retained austenite increases fatigue life due to retarding of crack propagation, resulting from the strain-induced transformation. Stress amplitude plays a significant role in the cyclic deformation behaviour of a material. Ackermann et al. ${ }^{[26]}$ found that the observed pronounced cyclic hardening depended on the martensite formation rate and the plastic strain amplitude. There are also literature reports indicating that the cyclic strengthening or weakening phenomena in steels are not only related to the strain-induced transformation of austenite to martensite. Microstructural observation shows that initial hardening is associated with martensitic transformation and an increase of dislocation density. In the initial cycles of fatigue, high numbers of dislocations are generated during deformation. The dislocations interact with each other to form many dislocation tangles and immobile dislocations, reducing the possibilities of dislocation movement. In contrast, the cyclic softening is due to the annihilation and rearrangement of large amounts of dislocations and arise of lower energy dislocation substructures. On the other hand, Sugimoto $^{[27]}$ and Song ${ }^{[28]}$ studied the influence of microstructure on the fatigue properties of bainitic ferrite steels. They concluded that the cyclic behaviour is controlled not only by the RA (form and volume fraction) and the microstructure of $\mathrm{BF}$ but also by the long-range internal stresses resulting from the difference in flow stress between the matrix and the other phases. It can be summarised that the effect of transformation is significant for the LCF behaviour of steel, but also other mechanisms such as strain amplitudes, the interaction of constituent phases, density and mobility of dislocation affect the material properties.

The aim of the present work was to investigate the microstructure and mechanical properties of the carbide-free bainitic steel with a chemical composition designed to obtain the optimal relationship between strength and ductility after continuous cooling. The results of this study show that it is possible to develop a new bainitic steel with relatively low production costs (fewer technological stages on the production line, low content of carbon and alloying elements). The developed steel was subjected to low-cycle fatigue (LCF) tests and microstructural investigations, and the changes in the dislocation density and the volume fraction of the retained austenite were analysed after each deformation amplitude. 
Table I. Chemical Compositions of the Investigated Steel (Wt Pct)

\begin{tabular}{lccccccccc}
\hline Sample & C & Si & Cr & Mn & Ni & Mo & Al & Other & Fe \\
\hline S612 & 0.23 & 1.09 & 1.38 & 1.38 & 0.28 & 0.12 & 0.009 & 0.024 & bal. \\
\hline
\end{tabular}

\section{MATERIALS AND METHODS}

The chemical composition of the designed steel is given in Table I.

The Si content in this steel was greater than $1 \mathrm{wt}$ pct to avoid carbide precipitation in the retained austenite during the bainitic transformation. The chemical composition of the steel was designed to obtain the optimal microstructure and mechanical properties after hot deformation followed by natural cooling in still air. The steel was obtained in the form of a $70 \mathrm{~kg}$ ingot, with a cross section of $100 \times$ $100 \mathrm{~mm}^{2}$, after melting in the laboratory furnace. To reduce the thickness and to change the cast structure, the steel was subjected to rolling, which involved six passes into a bar with a $47 \times 70 \mathrm{~mm}^{2}$ cross section. Following subsequent cooling to ambient temperature, the bars were heated to $980{ }^{\circ} \mathrm{C}$, held at that temperature for 1 hour, and then freely cooled down in still air. Specimens for microstructural investigation were mechanically polished and etched with a 2 pet Nital solution to reveal the grain boundaries. The microstructures were examined using a Nikon Epiphot 220 optical microscope and a scanning electron microscope (SEM) Hitachi S-3500N. Fracture surfaces and fracture toughness tested specimens were also examined using the Hitachi S-3500N. Specimens for transmission electron microscopy (TEM) were prepared by slicing $100 \mu \mathrm{m}$ discs. Further thinning to reach a thickness appropriate for electron transparency was carried out via electropolishing at $55 \mathrm{~V}$ with a twin-jet unit technique, using a Struers electrolyte comprising $\mathrm{HNO}_{3}$ acid. Thin foils were then examined using a Jeol Jem 1200EX microscope operating at $120 \mathrm{kV}$. Electron backscatter diffraction (EBSD) measurements were performed for microstructural characterisation, with an acceleration voltage of $20 \mathrm{kV}$, a working distance of $18 \mathrm{~mm}$, a tilt angle of $70 \mathrm{deg}$, and a step size of $0.2 \mu \mathrm{m}$ using a Hitachi SU70 scanning electron microscope. The pattern acquisition and solution were determined using the HKL Channel 5 software. To eliminate spurious boundaries caused by orientation noise, a lower-limit boundary misorientation cut-off of $2.5 \mathrm{deg}$ was applied. The volume fraction of the RA, the carbon content in the austenite, and the dislocation density were analysed via X-ray diffraction (XRD) at room temperature using a Bruker D8 Discover diffractometer with filtered CoK $\alpha$ radiation. The retained austenite fraction was calculated by comparing the total intensity of the austenite and ferrite peaks using the Averbach-Cohen method. The XRD data were also used to calculate the carbon concentration $\left(C_{\gamma}\right)$ in the retained austenite lattice using the equation proposed by Dyson and Holmes ${ }^{[29]}[1]$ :

$$
\begin{aligned}
a_{\gamma}= & 3.578+0.033_{w \mathrm{C} \gamma}+0.00095_{w \mathrm{Mn}}-0.0002_{w \mathrm{Ni}} \\
& +0.0006_{w \mathrm{Cr}}+0.022_{w \mathrm{~N}}+0.0056_{w \mathrm{Al}}-0.0004_{w \mathrm{Co}} \\
& +0.0015_{w \mathrm{Cu}}+0.0031_{w \mathrm{Mo}}+0.0051_{w \mathrm{Nb}} \\
& +0.0039_{w \mathrm{Ti}}+0.0018_{w \mathrm{~V}}+0.0018_{w} \mathrm{~W}
\end{aligned}
$$

where $w$ is the concentration of different elements in weight (pct).

The lattice parameter $\left(a_{\gamma}\right)$ of austenite was calculated based on the four diffraction peaks: (lll 111$)$, (l $\left.\begin{array}{lll}2 & 0 & 0\end{array}\right)$, (2 2 0), and (3 11 1) using Bragg's law. Then, a precise lattice parameter of austenite was determined by correlating the values from Bragg's law against the Nelson-Riley $(\mathrm{N}-\mathrm{R})$ function, ${ }^{[30]}$ calculating a linear regression, and finding the $y$-intercept (where the $\mathrm{N}-\mathrm{R}$ function, and thus $\Delta a / a$ goes to zero). The lattice parameter was obtained by averaging the results of the three X-ray diffraction patterns.

The XRD method was also used for quantitative analysis of the dislocation density ( $\rho$ calculated using Eq. [2]) in the investigated steel. A broadening of the individual lines was calculated from the diffraction peak using a modified Williamson-Hall plot ${ }^{[31]}$ [2]:

$$
\rho=\frac{A \epsilon^{2}}{F b^{2}}
$$

where $A$ for bcc materials equals 14.4 with the Burgers vector of dislocations $\mathrm{b}$ along $\langle 111\rangle$ and for fcc metals, $A$ equals 16.1 with $\mathrm{b}$ along $\langle 110\rangle, \varepsilon$ represents the internal strain, and $F$ is a constant depending on the strain distribution, the value of $F$ was assumed to be 1 . The Burgers vectors for bcc and fcc crystal structures were estimated from the unit cell measurements determined using XRD.

Tensile testing was carried out in accordance with ASTM D638 at room temperature using an MTS810 hydraulic machine. The yield strength $\left(\sigma_{0.2}\right)$, ultimate tensile strength $\left(\sigma_{m}\right)$ and elongation at break $(A)$ were determined from the obtained stress-strain curves based on the average value of three samples. The strain hardening exponent $(n)$ and the strength coefficient $(K)$ were assessed using Eq. [3]:

$$
\sigma=K \varepsilon^{n}
$$

The values of $n$ and $K$ can be obtained from a log-log plot of the true stress $(\sigma)$ and true strain $(\varepsilon)$ up to the maximum load.

The low-cycle fatigue tests were performed at room temperature with an asymmetry ratio of $R=-1$, in stress-controlled mode. The following levels of plastic deformation were adopted: $\Delta \varepsilon p / 2=0.75,1$ and 1.25 pct. The experiment was carried out for three samples at each plastic deformation level, also using the MTS810 test machine. In addition, the fractured samples after LCF tests were analysed using SEM.

Following the standard, ASTM E399-90, the fracture toughness of the material $\left(K_{\mathrm{IC}}\right)$ was determined using the three-point bending (TPB) test. Bending specimens were prepared with the following specifications: $143 \mathrm{~mm}$ length, $34 \mathrm{~mm}$ width, $17 \mathrm{~mm}$ thickness, and $15 \mathrm{~mm}$ 
initial notch length. The tests were performed using a servo-hydraulic testing machine (MTS810) with a load capacity of $100 \mathrm{kN}$. The tests were carried out under displacement control with a sufficiently stiff loading machine. The maximum deflection at midspan was measured to be $0.49 \mathrm{~mm}$, at which point, the specimen was unloaded.

The hardness of each sample was measured by the Brinell method using a tungsten carbide ball with a 2.5 $\mathrm{mm}$ diameter under a $1.8 \mathrm{kN}$ load with a 10 seconds dwell-time, according to the ASTM E10 guidelines. The average value of the hardness measurements was determined based on 10 indentations for each steel sample.

\section{RESULTS AND DISCUSSION}

\section{A. Before $L C F$}

The optical microstructures and scanning electron micrographs of the bainitic steel before the LCF test are shown in Figure 1. The main component of the microstructure was bainitic ferrite $(\mathrm{BF})$ with retained austenite. This type of bainite is known as degenerated upper bainite (DUB), and it is formed because of an incomplete transformation of the prior austenite and stabilised as a result of carbon diffusion. ${ }^{[32]}$ The BF is often arranged in packets that can cut whole grains of the primary austenite. Therefore, it is clear that RA adopted a different morphology and form, i.e. thin layers (a few $\mathrm{nm}$ in thickness) located between the bainite laths and blocks. Since carbon has limited solubility in the ferrite phase, it tends to precipitate out as a cementite. Appropriate silicon content in the steel composition suppresses the formation of carbides and inhibits cementite precipitation from the austenite during the bainite transformation. The most common assumption is that $1.5 \mathrm{wt}$ pet addition of silicon is sufficient to completely avoid carbide precipitation in the retained austenite. ${ }^{[33-36]}$ Preventing carbide formation ensures that the carbon is available for stabilising the remaining austenite. In addition, carbon is rejected from the bainite into the RA, where it is significantly more soluble. The mechanical properties of the examined steels were strongly influenced by the stability of the retained austenite, which depended on multiple factors, including the chemical composition, morphology, size, distribution, stress state, temperature, isothermal bainite transformation parameters, and strength of the surrounding phases. ${ }^{[37-40]}$ Solutes dissolved in the austenite phase played a crucial role in determining the austenite stability during the transformation following cooling. For example, $\mathrm{C}$ and $\mathrm{Mn}$ are austenite stabilisers that reduced the temperature at which the transformation of austenite to martensite began (Ms). Carbon has a stronger stabilising effect than manganese, ${ }^{[41-43]}$ but $\mathrm{Mn}$ also hinders the transformation from austenite to $\mathrm{BF}$ during treatment. ${ }^{[44-47]}$ Retained austenite with a block morphology governs the mechanical properties because

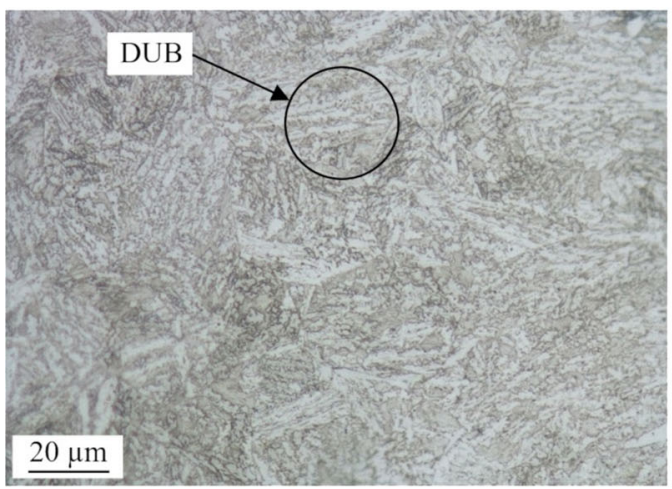

(a)

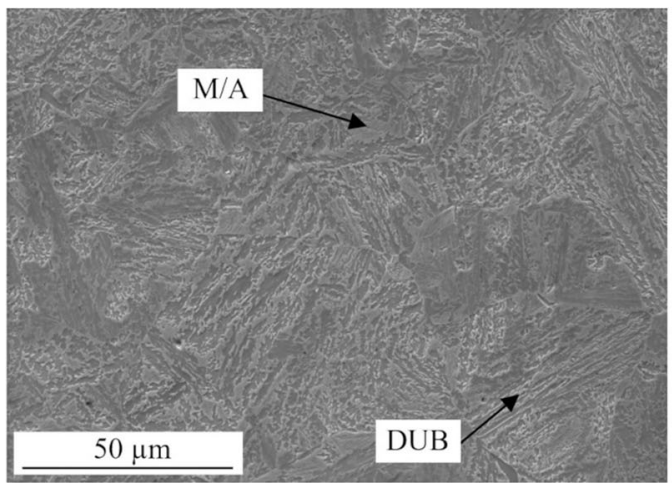

(c)

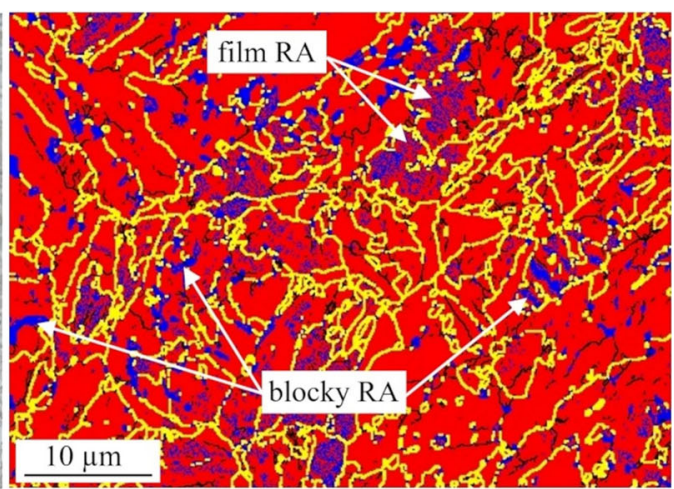

(b)

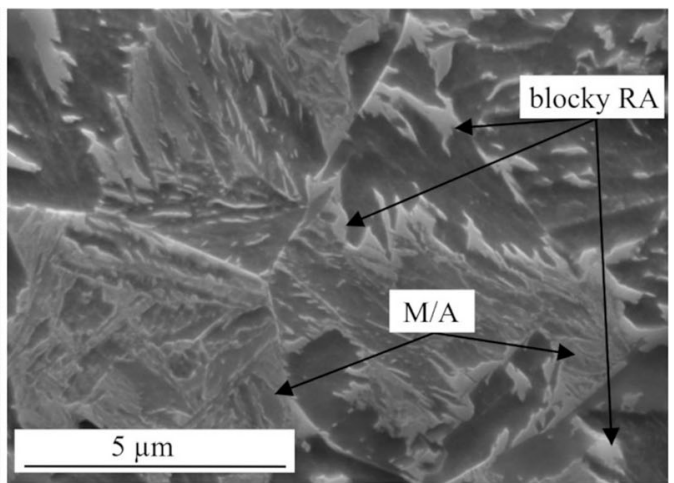

(d)

Fig. 1-Microstructures of the examined steel: light microscope image (a), EBSD results with phase identification $(b)$, SEM images $(c, d)$; $D U B$ degenerated upper bainite, $M / A$ martensite/austenite constituent, $R A$ retained austenite (Color figure online). 
of its potential to transform into martensite under stress. This is related to its lower stability and carbon concentration, which contribute to its facile transformation into martensite. ${ }^{[47-54]}$ In contrast, film-like RA is more stable for undergoing the martensitic transformation. In this case, the high carbon content in the austenite and the smaller surface on which the transformation into martensite can occur improves its mechanical stability. Therefore, it is clear that to obtain a more stable microstructure, it is necessary to undergo a large degree of bainitic transformation because of the reduced overall volume fraction of block-like coarse RA and the higher carbon content in this phase. This effect can be achieved by optimising the chemical composition and applying appropriate heat treatment conditions. When the investigated steel was cooled to room temperature, the untransformed austenite could be changed into morphologically complex phase components, especially in the middle of the grains where the austenite was less stable. This phase is generally known as a martensite/ austenite island $(M / A)$, which is characterised by enriched carbon. ${ }^{[55]}$

The observed austenite islands in the investigated steel were small (not exceeding $10 \mu \mathrm{m}$ ), which positively impacted their stabilisation. The RA layers were stabilised by the compressive stress exerted by the surrounding bainitic ferrite laths. Obtaining a microstructure consisting of bainitic ferrite laths separated by a thin film of RA, a small fraction of blocky austenite and $M / A$ islands ensures high-strength properties and significant cracking resistance. This is because micro-crack must overcome numerous interfaces (e.g. bainitic ferrite/austenite boundaries) and pass through the austenite area, which is a plastic phase. In this case, the energy of crack propagation can be absorbed by the plastic deformation of austenite. ${ }^{[56]}$ The average thickness of the bainitic ferrite laths was approximately $13 \pm$ $1 \mu \mathrm{m}$, and the size of the retained austenite in the form of blocks ranged from 0.3 to $0.9 \mu \mathrm{m}$. EBSD studies also confirmed that austenite existed in the form of thin films between the bainitic ferrite and block-like forms. The red colour in Figure 1(b) represents bainitic ferrite and blue represents austenite. The yellow lines correspond to the high angle grain boundaries (HAGBs; misorientation $\geq 15 \mathrm{deg}$ ) and the black lines denote low angle grain boundaries (LAGBs; misorientation 2 to $15 \mathrm{deg}$ ). The misorientation angle distribution in this steel was also analysed in this work and is discussed later in the text.

The tested steel's microstructure was also observed with TEM for a more detailed analysis, and the results are summarised in Figure 2. Figure 2(a) shows the bright-field TEM micrographs and the selected area electron diffraction (SAED) pattern of the examined steel. The results indicated that the microstructure was primarily composed of thin films of RA (varying between 30 and $40 \mathrm{~nm}$ in thickness) located between fine BF laths (thickness $150 \mathrm{~nm}$ ). There was also a secondary phase in the form of small blocks of retained austenite, which contained very small laths (lengths $<$ $0.7 \mu \mathrm{m})$. The electron diffraction patterns suggested that the lath structure comprised twinned martensite $\left(\alpha^{\prime}\right)$ (Figure 2(c)) with a near standard Kurdjumov-Sachs

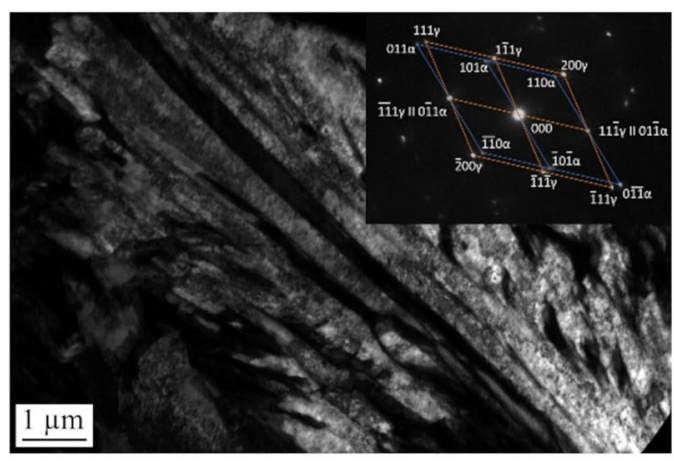

(a)

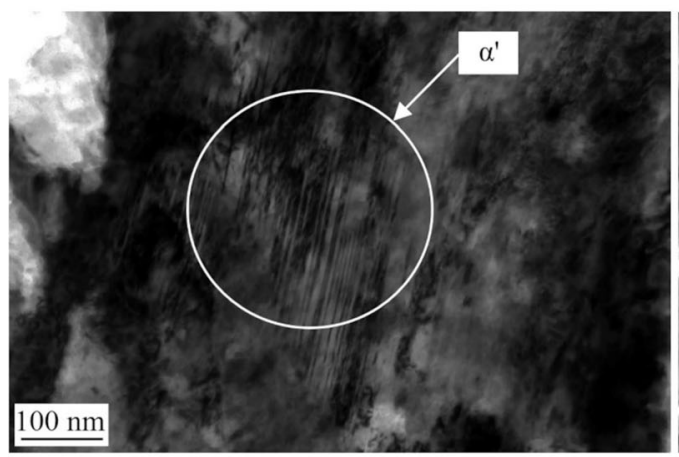

(c)

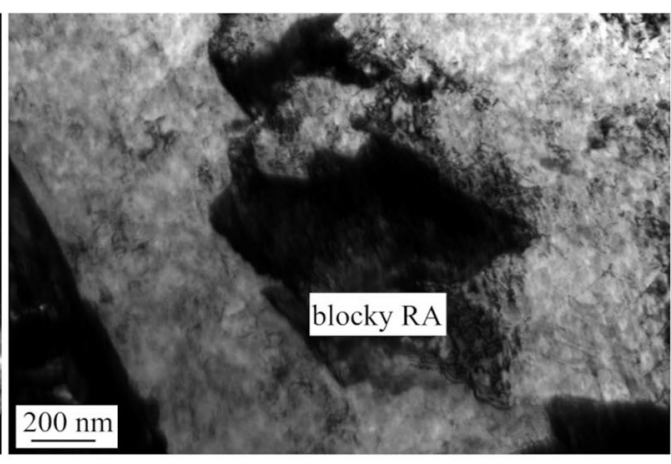

(b)

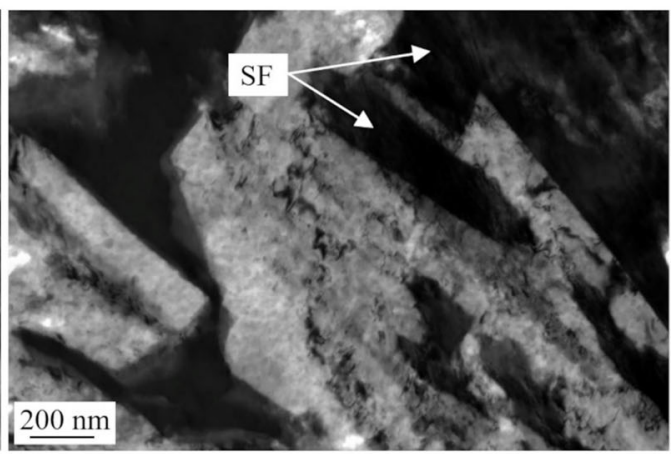

(d)

Fig. 2-Bright-field TEM: laths of bainitic ferrite and retained austenite and their corresponding diffraction patterns (SADP) (a), blocky RA and the high density of dislocations in ferritic bainite $(b)$, twinned martensite $\alpha^{\prime}(c), S F$ stacking faults in retained austenite $(d)$. 
orientation relationship with the austenite matrix. This area is generally known as a martensite-austenite island, which was formed during continuous cooling to room temperature and was enriched with carbon. ${ }^{[47]}$ This type of microstructure indicated that the high concentration of carbon in the $M / A$ islands was a consequence of carbon partitioning into austenite during the transformation. ${ }^{[57-59]}$ Another important element of the microstructure that was visible during microscopic observations was the presence of stacking faults (SF) in the thin layer of RA. During the bainitic transformation, the growth of BF induced the relaxation of the retained austenite and the formation of a high density of dislocations in the BF phase and SF. This phenomenon impacted the growth of bainitic ferrite by restricting the mobility at the bainitic ferrite/austenite interface and determined the size of the BF laths. This behaviour of the material supported a displacive mechanism during transformation. Similar results were also obtained for high-strength bainitic steel $(\mathrm{Fe}-0.27 \mathrm{C}-1.55 \mathrm{Mn}-1.30 \mathrm{Si}-$ $0.5 \mathrm{Cr}-0.03 \mathrm{~V}-0.15 \mathrm{Mo}$ wt pct), where the bright-field TEM images show the formation of SF during bainitic growth. ${ }^{[60]}$ It should be noted that a high density of dislocations was observed (Figure 2(b)) in the matrix around the $M / A$ islands, and these dislocations were generated as a result of the volume change during the displacive transformation of austenite into martensite. ${ }^{[55,61]}$ The dislocation densities of the bainitic ferrite and retained austenite were determined to be $2.73 \times$ $10^{15}$ and $1.36 \times 10^{14} \mathrm{~m}^{-2}$, respectively, based on the diffraction peaks.

Table II presents the total volume fraction of the identified phases, as determined via X-ray analysis. These data revealed the presence of bainitic ferrite and austenite. No diffraction peaks derived from carbides were observed, thus confirming that the carbide-free bainite structure was formed during the steel production. Also, no other phases were found, e.g. martensite, which has been identified in the bright-field TEM micrograph. This phenomenon can be attributed to the detection threshold of the XRD experiment and the small fraction of the $\alpha^{\prime}$ phase in the volume of the S612 steel. Following the Reference 62, it is possible to determine the fraction of retained austenite in the form of thin films and blocks using the relation (Eq. [4] ${ }^{[62]}$ ):

$$
\frac{V_{\gamma f}}{V_{\gamma b}}=\frac{0.15 V_{\alpha b}}{V_{\gamma}-0.15 V_{\alpha b}}
$$

where $V_{\alpha \mathrm{b}}$-volume fraction of bainitic ferrite, $V_{\gamma}$ - total volume fraction of retained austenite, $V_{\gamma \mathrm{f}}$-volume fraction of retained austenite in the form of thin layers, $V_{\gamma \mathrm{b}}$ - volume fraction of retained austenite in the form of blocks.

Table II. Volume Fraction of Detected Phases in S612 Steel and Carbon Content $C_{\gamma}$ (Pct)

\begin{tabular}{ccccc}
\hline$V_{\alpha \mathrm{b}}$ & $V_{\gamma}$ & $V_{\gamma} f$ & $V_{\gamma} b$ & $C_{\gamma}$ \\
\hline 85 & 15 & 13 & 2 & 1.22 \\
\hline
\end{tabular}

According to the calculations using Eq. [4], the retained austenite in the forms of thin films corresponded to approximately 13 pct (volume fraction).

It is known that bainitic microstructures formed at low temperatures contain retained austenite mainly in the form of thin films because the bainitic transformation occurred to a greater extent. In addition, the RA with a layered morphology gives the optimal relationship between strength and ductility. However, when the thickness of RA is a few nm, the transformation-induced-plasticity effect cannot occur. This could be because of the high carbon content in the RA or because the transformation was stopped by the compressive stress exerted by the surrounding bainitic ferrite laths. ${ }^{[63,64]}$ Austenite in a block-like form contains a lower carbon concentration than the thin films and plays a crucial role in the initialisation of cracks, owing to its low stability; this can bring about an unexpected transformation of retained austenite into martensite. The analysis of the volume fraction of RA and microscopic observations of the investigated S612 steel indicated that the thickness and volume fraction of the austenite thin films allowed the TRIP effect to occur.

The mechanical properties evaluated based on the engineering tensile stress-strain curve (Figure 3), as well as the hardness measurements and the fracture toughness coefficient are presented in Table III. In general, the S612 steel combined high strength with good ductility, and simultaneously exhibited behaviour characterised by moderated strain hardening. Most importantly, its resistance to crack propagation was also higher than the requirements for traditional steel rails. The well-balanced amount of elements in the chemical compositions of the studied steel stabilised the austenite phase at room temperature and induced favourable mechanical properties. For example, Si has very low solubility in $\mathrm{Fe}_{3} \mathrm{C}$ and hence kinetically retards precipitation during the bainitic transformation (low mobility of Si compared to C). Consequently, Si-containing steels show an increase in austenite stability via $\mathrm{C}$ partitioning, which results in improved yield strength, ultimate tensile strength and toughness. ${ }^{[65]}$

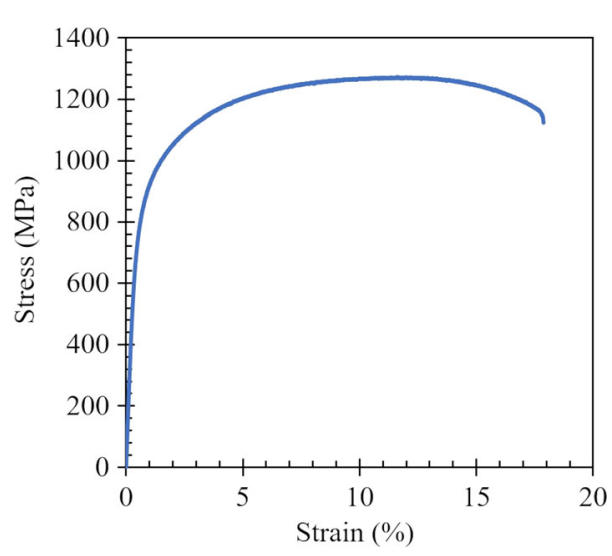

Fig. 3-Stress-strain curve for S612 steel. 
Table III. Mechanical Properties of the S612 Steel

\begin{tabular}{lccccr}
\hline $\mathrm{HB}_{2.5 / 187.5}$ & $K_{\mathrm{IC}}\left(\mathrm{MPa} \times \mathrm{m}^{0.5}\right)$ & $\sigma_{0.2}(\mathrm{MPa})$ & $\sigma_{\mathrm{m}}(\mathrm{MPa})$ & $A(\mathrm{Pct})$ & $\mathrm{E}(\mathrm{GPa})$ \\
\hline 377 & 71 & 780 & 1250 & 17 & 205 \\
\hline
\end{tabular}

This behaviour of the material during deformation resulted from its microstructure, which controlled the degree of uniform elongation. The smaller size of the RA particles, which supported the greater stability of the transformation, contributed to a more uniform elongation by delaying the necking of the material. Comparing the obtained $K_{\mathrm{IC}}$ coefficient with literature references, it was clear that the value obtained in this work was higher compared to other steels with similar chemical compositions and microstructures. ${ }^{[66-68]}$ However, in Reference 69, the reported $K_{\mathrm{IC}}$ value was higher by 28 pet $\left(98 \mathrm{MPa} \times \mathrm{m}^{0.5}\right)$. This effect is related to the presence of nanometric bainite and the special thermomechanical treatment. However, in that case, the steel contained expensive elements, the presence and high proportion of which significantly increased the production costs of rails.

One common method for describing the work-hardening characteristics of the carbide-free bainitic steel during tensile deformation is the Hollomon equation. ${ }^{[70-73]}$ The obtained $\ln \sigma-\ln \varepsilon$ curve of the tested S612 steel was non-linear and indicated the presence of multiple strain hardening mechanisms. The different stages of work hardening were related to different activated deformation mechanisms over the strain range corresponding to each state. The first state had a high strain hardening exponent $\left(n_{1}=0.11\right)$, while the second stage had a lower one $\left(n_{2}=0.02\right)$. The corresponding strength coefficients, $K$, were $1633 \mathrm{~Pa}$ and $1286 \mathrm{MPa}$, respectively. In the first stage, work hardening occurred because of changes in the distribution, density, and movement of mobile dislocations in the microstructure. Additionally, the presence of RA in the forms of thin films located between the bainitic ferrite laths inhibited the initiation of cracks and increased the $n$ and $K$ parameters. Moreover, the chemical composition of the S612 steel contained substitute alloying elements, which strengthened the material by blocking dislocations in their initial positions and inhibiting their movement by limiting cross-slip. The n parameter and the $K$ coefficient of the second stage of work hardening were lower than for the first stage. Following increased deformation, in the deformed microstructure, the dislocation tangles created during the initial hardening into cell structures were annihilated and rearranged, resulting in a rapid decrease of the $n$ and $K$ values.

\section{B. After $L C F$}

Figure 4 presents the cyclic stress responses of the investigated steel at various strain amplitudes as a Wöhler plot and hysteresis loops for different strain amplitudes. In the early fatigue cycles, cyclic hardening occurred, thus indicating changes in the microstructure, such as increased dislocation density or phase transformation. Afterwards, the material showed cyclic softening at all strain amplitudes. However, the amount of cyclic softening increased with increasing strain amplitude, and the duration of the cyclic saturation stage became shorter. For half of the fatigue life cycle $\left(N_{f} / 2\right)$, it was considered a saturated cycle for generating a cyclic stress-strain curve. The relevant literature states that various bainite steels can exhibit both cyclic hardening and softening during low-cycle fatigue. ${ }^{[74,75]}$ Cyclic hardening is associated with many factors related to the evolution of microstructure. First, it is caused by high numbers of dislocations generated in the initial cycles of deformation. When the density of the mobile dislocations decreases, the initial cyclic hardening occurs. Second, the transformation of the retained austenite to martensite increases stress during the initial deformation stage. In contrast, the cyclic softening behaviour is related to the deviation of the material from the equilibrium state, removal of dislocation pinning, generation of unpinned dislocations and dynamic recovery leading to a reduction in the internal stress. ${ }^{[76-79]}$ The number of cycles to failure $\left(N_{f}\right)$ and the range of plastic deformation $(\Delta \varepsilon p)$ are related according to the Coffin-Manson equation (Eq. [5]):

$$
\frac{\Delta \varepsilon_{p}}{2}=\varepsilon_{f}^{\prime}\left(2 N_{f}\right)^{c}
$$

The determined values of the fatigue ductility coefficient $\left(\varepsilon_{f}^{\prime}\right)$ and the fatigue ductility exponent $(c)$ were 9.29 and -0.4 , respectively. For many metals, the $\varepsilon_{f}^{\prime}$ coefficient is approximately equal to the true fracture strain, $\varepsilon_{f}^{\prime}$, while the value of the $c$ exponent usually varies between -0.5 and -0.7 . A smaller value of $c$ indicates in a longer fatigue lifetime. ${ }^{[80]}$ In the investigated S612 steel, similar values of the fatigue ductility exponent were obtained. The determined fatigue ductility coefficients were similar to values obtained in other work. ${ }^{[19,81]}$ Comparing the investigated steel with previously tested pearlitic steel ${ }^{[82]}$ revealed that the bainitic steel exhibited approximately 40 pct higher yield strength and twice the total elongation. The steel with a bainitic structure broke earlier at all strain amplitudes, but at much higher stress values than the pearlitic steel, this means that the S612 steel can work at higher stress values.

The cyclic hardening ratio (CHR) and cyclic softening ratio (CSR) are two important parameters for characterising the cyclic deformation behaviour of materials. Therefore, these parameters were determined based on Eqs. [6] and [7], respectively: 


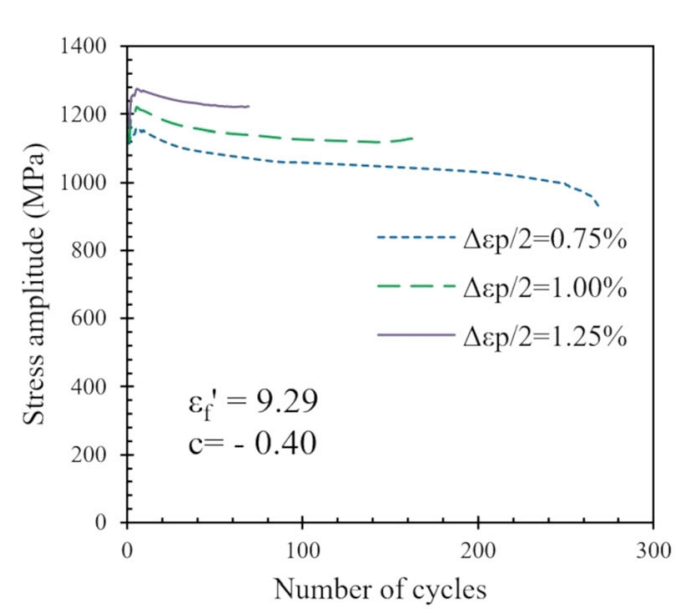

(a)

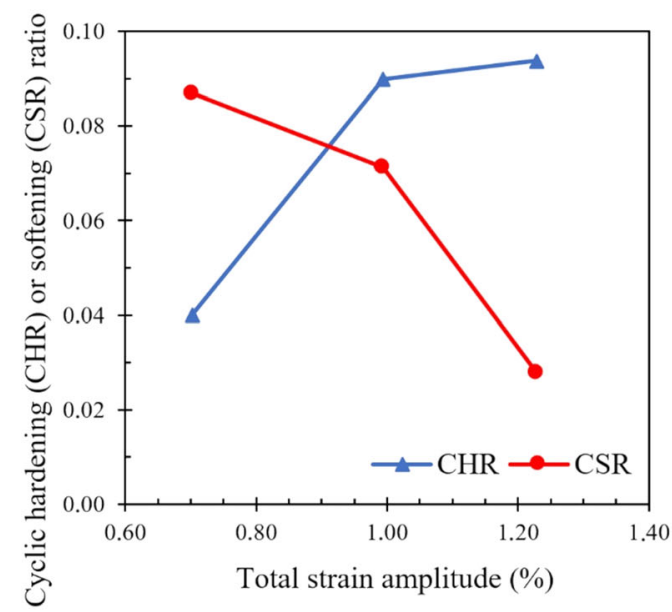

(c)

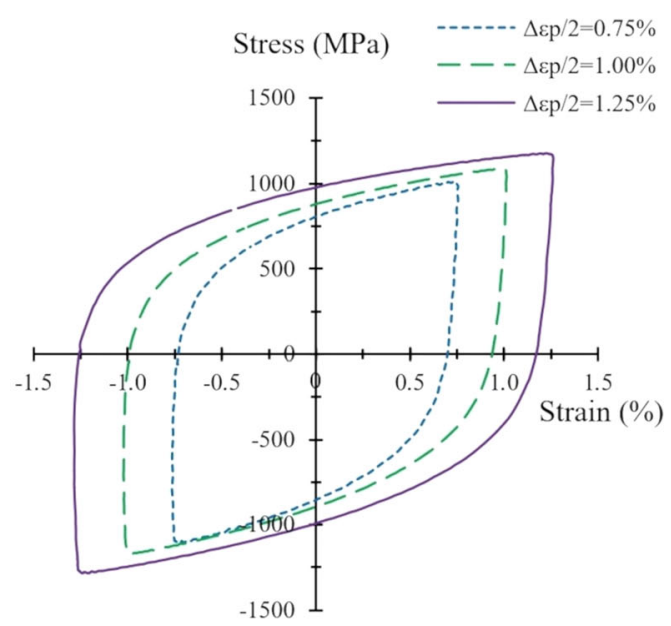

(b)

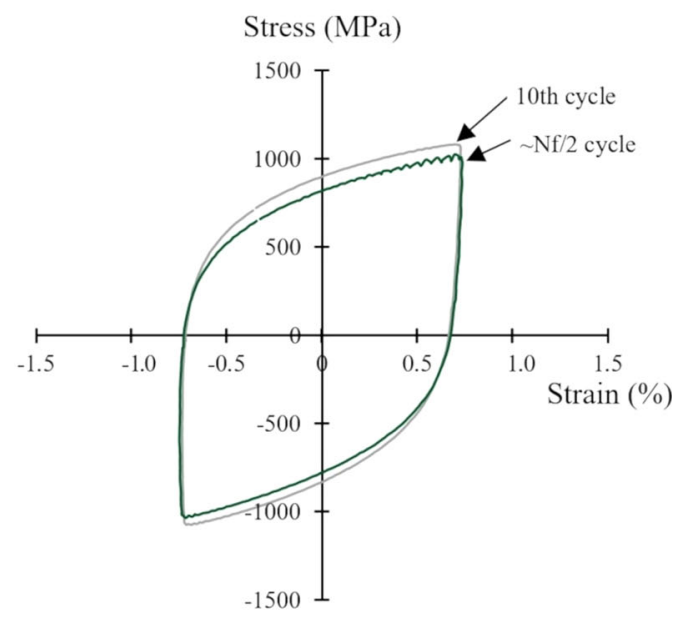

(d)

Fig. 4-Results of the low-cycle fatigue tests: evolution of the stress amplitude vs the number of strain cycles $(a)$, stabilised hysteresis loops at half fatigue life $(b)$, cyclic hardening and softening ratios $v s$ the total strain amplitude $(c)$, exemplary hysteresis loops for stress amplitude 0.75 pct at the tenth cycle and half fatigue life $(d)$.

$$
\begin{array}{r}
\mathrm{CHR}=\frac{\sigma_{\max }-\sigma_{1}}{\sigma_{1}} \\
\mathrm{CSR}=\frac{\sigma_{\max }-\sigma_{N_{f} / 2}}{\sigma_{\max }}
\end{array}
$$

where $\sigma_{1}, \sigma_{\max }$, and $\sigma_{N f / 2}$ represent the stress amplitude at the first cycle, the maximum stress amplitude, and the stress amplitude at the half lifetime, respectively. The CHR and CSR are plotted in Figure 4(c) as a function of the total strain amplitude. When the value of the strain amplitude was $<1$, the cyclic hardening ratio increased rapidly. At values $>1$, the $\mathrm{CHR}$ parameter continued to increase, but more slowly. In contrast, the CSR decreased at all tested amplitudes. Accordingly, the CSR was smaller than the CHR at any given strain amplitude. The only exception from this tendency was at the lower amplitude $\Delta \varepsilon p / 2=0.75$ pct.
The macroscopic changes in the material during cyclic deformation are related to the shape of the cyclic hysteresis loop. One common fundamental method for describing the low-cycle fatigue of a material involves analysing the loop and cyclic deformation curves. The area under the hysteresis loops provides information about the plastic strain energy of the material under fatigue. The hysteresis loops for all amplitudes exhibited slight asymmetry because the compression peak stress was higher than the tension. This phenomenon is probably related to the transformation of RA into martensite during deformation. Martensite formation is accompanied by an increase in the volume of the unit cell in relation to austenite, which leads to a rise in the specific volume and the introduction of compressive stresses. Their presence is visible on the hysteresis loop, manifesting itself in a higher compressive stress value. In addition, the presence of serrated flow can be observed on the hysteresis loops in the initial cycles of the 
working material, and after approximately $N_{f} / 2$ cycles, this effect intensified significantly (Figure 4(d)). Also, note that the serration phenomenon is more pronounced during compressive stress. The effect of force oscillation during low-cycle fatigue is visible across all applied deformation amplitudes. This material behaviour could be a manifestation of the dynamic strain ageing (DSA) occurrence in steel, ${ }^{[83]}$ which may occur at room temperature in low-alloy, low-carbon steel following cold working, i.e. static strain ageing (SSA), or during plastic deformation, as is the case with the tested steel. Strain ageing strengthens the steel as a result of pinning dislocations by interstitial atoms present in the solid solution (mainly carbon and nitrogen atoms, ${ }^{[84]}$ but could also be atoms of other elements, e.g. $\mathrm{Cr}^{[85]}$ ). The rapid release of dislocations into the atmosphere was accompanied by a decrease in the stress-strain curve because these dislocations can continue their movement. After applying several cyclic loads, the serration phenomenon gradually disappeared, and the hysteresis loops became smooth, which is probably due to the increased dislocation density and their reduced interactions with the dissolved substance atoms. The plastic instability phenomenon was observed in steels with Cr content, ${ }^{[86,87]} \mathrm{Mn}$ steels, ${ }^{[88]}$ austenitic stainless steels, ${ }^{[8]}$ and dual-phase steels. ${ }^{[90]}$

Upon comparing the cyclic stress-strain curves with the monotonic behaviour, it was clear that most of the materials exhibited a mixed type of cyclic behaviour. The material could undergo cyclic hardening or softening during each consecutive cycle until saturation occurred. The same applies to the investigated steel, which showed clearly visible differences in behaviour during cyclic deformation. To confirm these phenomena, the volume fraction of retained austenite in individual states was analysed and microscopic observations were made using TEM; the results are presented in Figure 5. The cyclic behaviour of the S612 steel was characterised by cyclic hardening in the first of several fatigue cycles, followed by a progressive transition to cyclic softening without saturation until sample breakage. In the microstructure of the material during cyclic hardening, typical interactions between dislocations, and between dislocations and particles occurred, and new dislocations were generated in the initial stages of deformation. For the tested S612 steel, in addition to the reorganisation and interactions of the dislocations, it was possible to form martensite from the retained austenite as a result of stress-induced plastic deformation. In turn, the softening mechanisms involved the rearrangement of dislocation tangles created during the initial hardening into cell structures with lower dislocation density. Unpinning dislocations from solute atmospheres allowed the formation of new mobile dislocations. During cyclic deforming of the material, these mechanisms reached a balance, and cyclic saturation was achieved. The results from microscopic observations confirmed that dislocations underwent reorganisation and created low-energy configurations, thereby reducing the material strengthening.

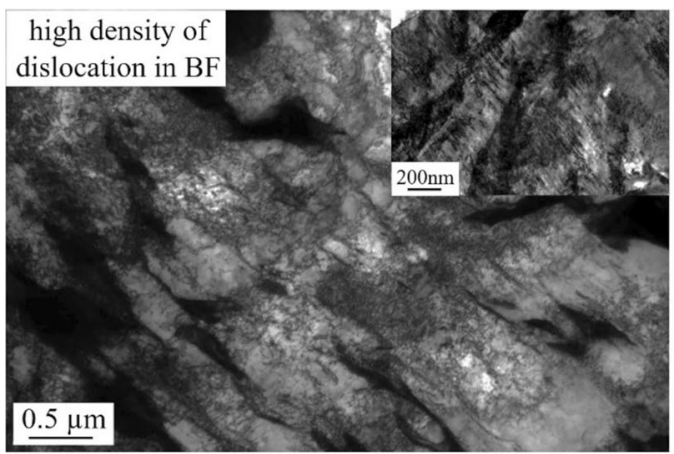

(a)

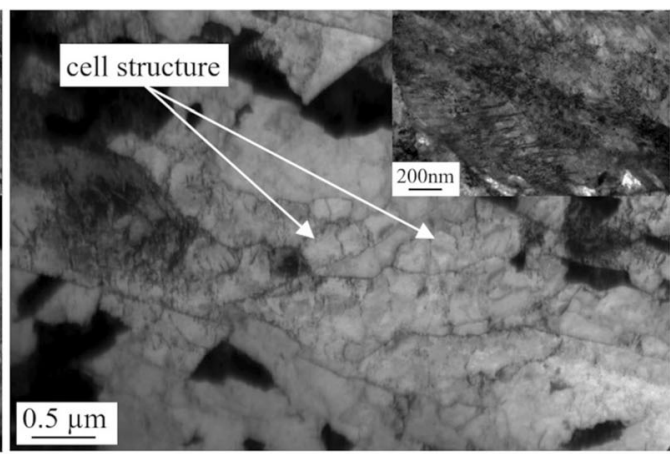

(b)

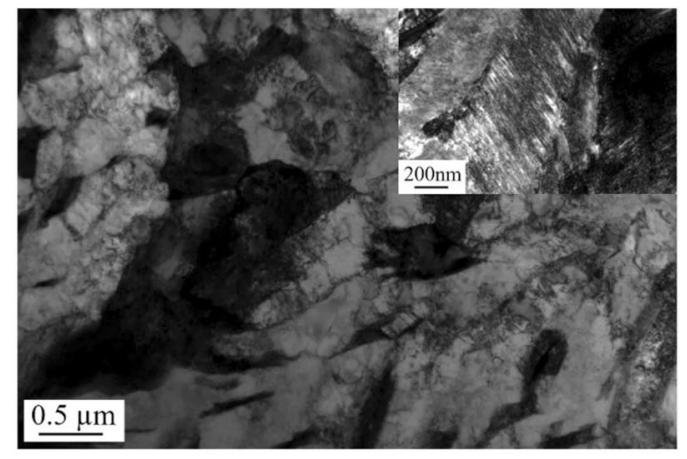

(c)

Fig. 5-Bright-field TEM micrographs of the investigated steel after LCF at strain amplitudes of $\Delta \varepsilon p / 2=0.75$ pct $(a), \Delta \varepsilon p / 2=1$ pct $(b)$, and $\Delta \varepsilon p / 2=1.25$ pct $(c)$-inside the twinned martensite $\alpha^{\prime}$. 


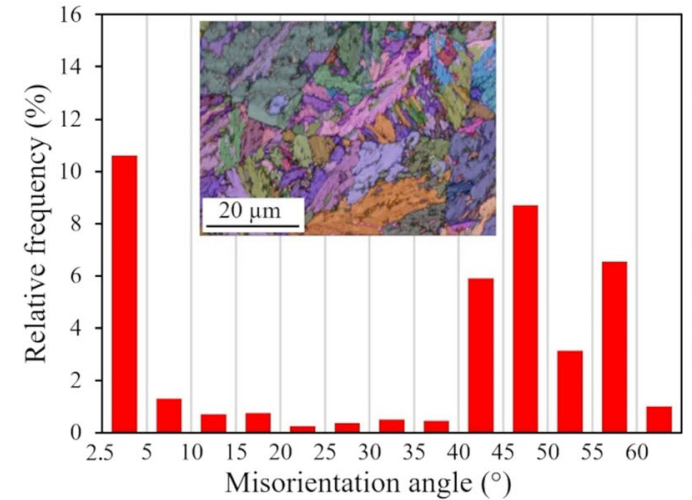

(a)

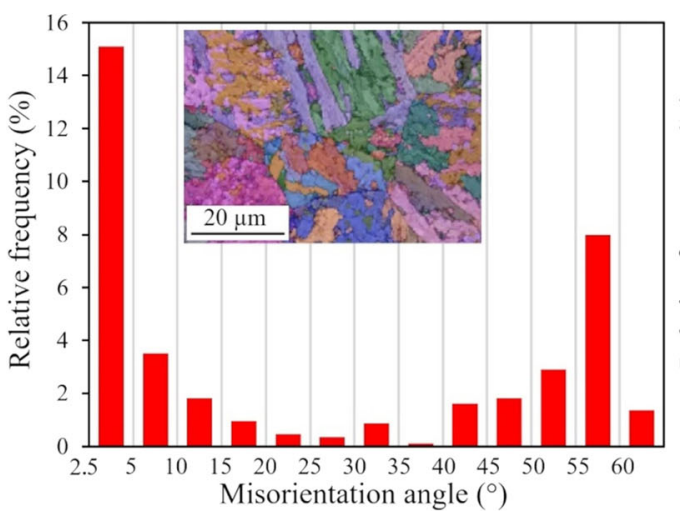

(c)

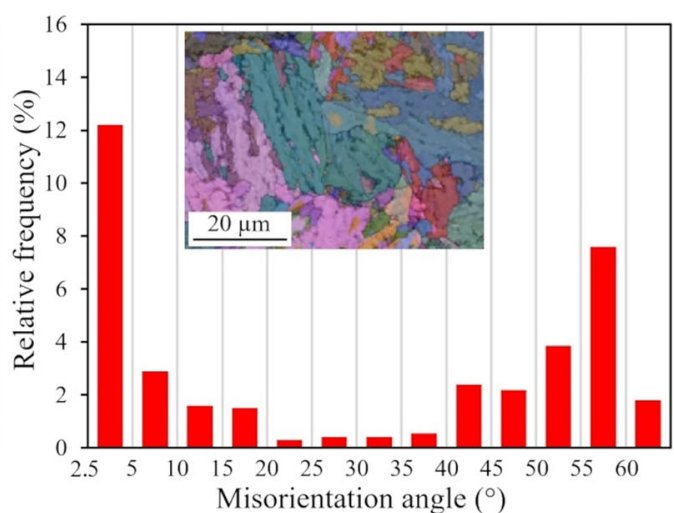

(b)

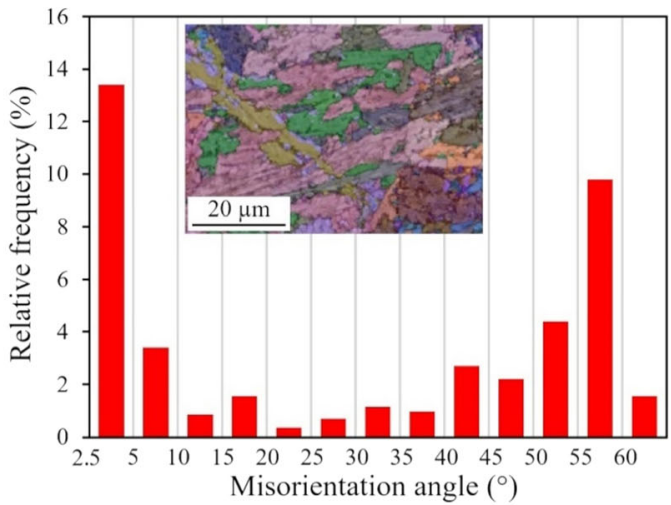

(d)

Fig. 6-Misorientation angle distributions of the investigated steel before $(a)$ and after LCF at strain amplitudes of $\Delta \varepsilon p / 2=0.75$ pct $(b), \Delta \varepsilon p / 2$ $=1$ pct $(c)$, and $\Delta \varepsilon p / 2=1.25$ pct $(d)$, insets show the EBSD Euler maps (Color figure online).

Analysis of the misorientation angle distributions and orientation images for samples before and after cyclic deformation are shown in Figure 6. Four different orientation relationships (OR) between crystallographic austenite/ferrite orientations are often cited in the literature, namely, Bain, ${ }^{[91]}$ Kurdjumov-Sachs $(\mathrm{K}-\mathrm{S}),{ }^{\left[{ }^{[2]}\right]}$ Nishiyama-Wasserman $(\mathrm{N}-\mathrm{W}),{ }^{[93,94]}$ and Greninger-Troiano $(\mathrm{G}-\mathrm{T}) .{ }^{[95]}$ Furthermore, a diverse combination of intermediate orientation relationships is often observed. They vary from one another by only a few degrees (e.g. the difference between $\mathrm{K}-\mathrm{S}$ and $\mathrm{N}-\mathrm{W}$ is about $5.26 \mathrm{deg}$ ). The crystallographic OR observed between austenite and ferrite led to several equivalent so-called variants of ferrite with one austenite orientation. For example, the $\mathrm{K}-\mathrm{S}$ and $\mathrm{G}-\mathrm{T}$ relationships led to 24 variants of ferrite, the $\mathrm{N}-\mathrm{W}$ OR led to 12 , and the Bain OR led to three. The distribution diagram in Figure 6(a) shows two maxima at high angle grain boundaries (approximately 45 and $60 \mathrm{deg}$ ). Based on the results reported by Beladi et al. ${ }^{[96]}$ for carbide-free bainitic steel, a misorientation angle of $46 \mathrm{deg}$ represented the misorientation angle between $\mathrm{BF}$ laths and $\mathrm{RA}$ with the ideal $\mathrm{N}-\mathrm{W}$ orientation relationship. Boundaries with misorientations $<15$ deg are considered low angle boundaries, which correspond to lath boundaries of martensite or bainitic ferrite ${ }^{[97,98]}$ After the LCF tests, the increased low angle misorientation was mainly due to the increased deformation substructure after cyclic deformation. LAGBs are low-energy dislocation arrangements that are formed during deformation. There was also a relatively high fraction of boundaries with misorientations in the range of 2.5 to $10 \mathrm{deg}$, which were assigned to martensite. Typically, these boundaries were located inside the martensite laths, forming sub-laths. ${ }^{[99]}$ In turn, the misorientation angles of the materials after cyclic deformation were in the range of 55 to $60 \mathrm{deg}$, increasing with increased strain amplitude. Based on the previously reported results, ${ }^{[100-102]}$ this range corresponds to the presence of martensite packages. This microstructure is characterised by ferrite/martensite crystallographic packets with austenite in the $\mathrm{K}-\mathrm{S}$ orientation.

The volume fraction of retained austenite changed with the level of plastic deformation measured by XRD (Figure 7). Because of the low intensity of the retained austenite in the diffraction pattern, it was impossible to estimate the dislocation density for the strain amplitude, $\Delta \varepsilon p / 2=1.25$ pct. The RA decreased with increasing strain amplitudes, the amount of retained austenite at lower strain amplitudes $(\Delta \varepsilon p / 2=0.75 \mathrm{pct})$ was approximately twice as low as the austenite content at the beginning of the fatigue tests. This suggested that a large deformation-induced transformation occurred during fatigue cycling. With increasing deformation amplitude, the volume fraction of RA in the microstructure of the S612 steel was further reduced. An appropriate volume 
fraction of retained austenite led to an increased fatigue life due to the inhibition of crack initiation and the delay of crack propagation, both of which resulted from the strain-induced transformation of RA to martensite. ${ }^{[25,103]}$ The TRIP phenomenon is a symptom of significantly increased plasticity resulting from a phase change during deformation. The austenite transformed into martensite (a stronger phase) by a mechanism associated with energy absorption, which resulting in a hardening of the material. On the other hand, the carbon content in austenite increased because the retained austenite present in the steel contained a different carbon content; as it cooled freely in still air, the temperature of its formation was different. However, the mechanical stability of austenite increased with increasing carbon content. Thus, during the cyclic deformation, the austenite with lower carbon content was transformed in the beginning.

The results indicated that the $\rho_{b}$ value fell rapidly from $2.73 \times 10^{15} \mathrm{~m}^{-2}$ (initial state) to $1.54 \times 10^{15} \mathrm{~m}^{-2}$ $(\Delta \varepsilon p / 2=0.75 \mathrm{pct})$ and $1.12 \times 10^{14} \mathrm{~m}^{-2}(\Delta \varepsilon p / 2=1 \mathrm{pct})$, whereas the $\rho_{\mathrm{a}}$ rose from $1.36 \times 10^{14}$ to $1.08 \times$ $10^{15} \mathrm{~m}^{-2}(\Delta \varepsilon p / 2=0.75$ pct $)$ and $1.58 \times 10^{15} \mathrm{~m}^{-2}$ $(\Delta \varepsilon p / 2=1 \mathrm{pct})$. This phenomenon can be explained by the fact that during deformation, dislocations inside

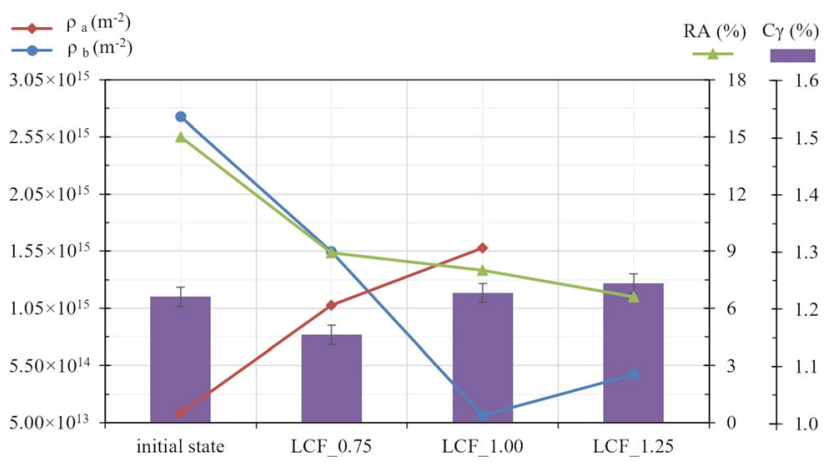

Fig. 7-Differences in dislocation density $\left(\rho_{a}\right.$ dislocation density in the austenite, $\rho_{b}$ dislocation density in the bainite), the volume fraction of retained austenite (RA) and carbon content in austenite $\left(C_{\gamma}\right)$ at the initial state and after LCF tests. the bainitic ferrite moved to the ferrite/austenite interface and were absorbed by the softer RA phase.

Moreover, the number of dislocations going into the retained austenite phase was greater than the number of dislocations generated in the bainitic ferrite during deformation, this led to a rapid decrease in their density in the bainite at the expense of growth in the austenite. Wang et al. analysed the microstructure of low-carbon austenitic steel after applying tension at various stages of deformation, and they observed that the average dislocation density in bainite during deformation was lower than that before deformation, a new effect was used to explain this phenomenon, termed the dislocations absorption by retained austenite (DARA) effect. ${ }^{[104]}$

The fractures observed after the fatigue test were also analysed. Figure 8 shows example images of fractures related to deformation, $\Delta \varepsilon p / 2=0.75$ pct.

The breakage zone itself contained cleavage ridges (sharp and extended edges) and cavities characteristic of malleable cracking (marked with arrows). The presence of clear plastic deformation traces in the residual fracture zone was observed in each of the tested samples, indicating plastic deformation. These results suggested that the S612 carbide-free bainitic steel underwent characteristic mixed quasi-cleavable fractures.

\section{SUMMARY AND CONCLUSIONS}

This paper presents the microstructural characterisations and mechanical properties of a novel carbide-free bainitic steel. Its chemical composition was designed to obtain a material with optimal mechanical properties (i.e. high tensile strength at high elongation) after rolling and air cooling. An appropriate silicon content increases the carbon activity in the solid solution, which suppresses the formation of carbides and inhibits cementite precipitation from the austenite during bainite transformation. An increase in the volume fraction of bainitic ferrite in the microstructure is needed to consume large regions of untransformed austenite, which under stress transform to hard martensite. The following conclusions can be drawn based on the results:
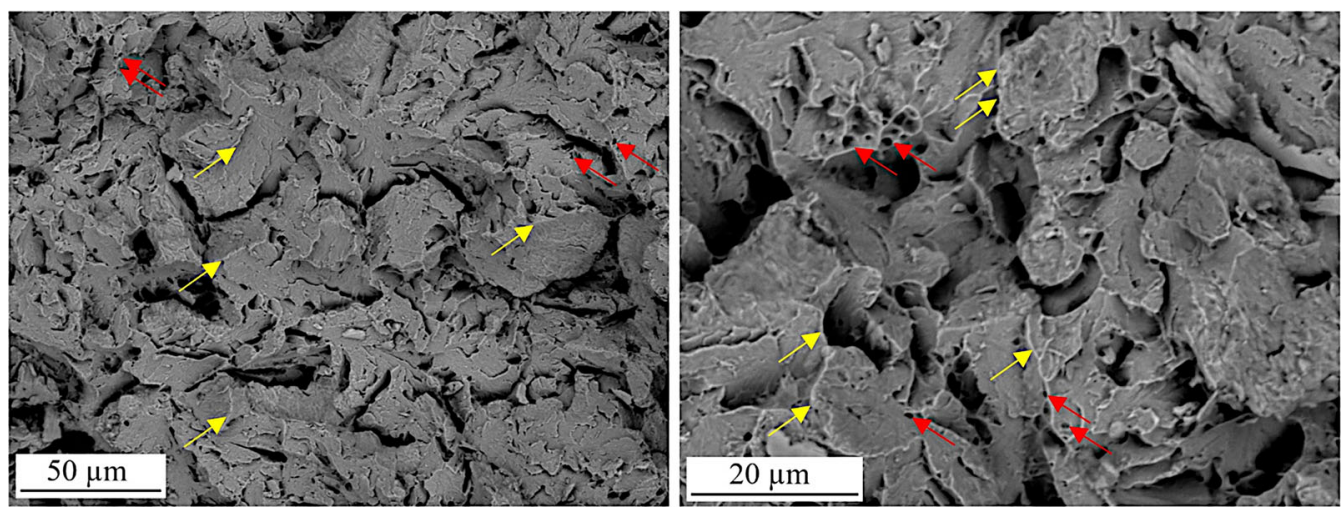

Fig. 8-Fatigue fractographs (SEM) of investigated steel after LCF tests at $\Delta \varepsilon p / 2=0.75$ pct. 
1. The analysed steel had a microstructure comprising degenerated upper bainite, which contained retained austenite mainly in the form of thin layers not exceeding $50 \mathrm{~nm}$. Moreover, the retained austenite in the form of blocks, whose dimensions ranged from 0.3 to $0.9 \mu \mathrm{m}$, were also identified.

2. The obtained microstructure allowed for highstrength parameters while maintaining high ductility and resistance to brittle cracking. Retained austenite in the form of blocks played an important role in the initiation of cracks, owing to their low stability, and they induced the unexpected transformation of retained austenite into martensite. Moreover, the smaller retained austenite size, which had higher transformation stability, contributed to higher uniform elongation.

3. During low-cycle fatigue in the tested steel, cyclic hardening occurred in the first deformation cycles, but after about 10 cycles, a slight softening of the material was observed.

4. Microstructural observations and measurements of the dislocation density revealed that the initial work hardening of the steel did not only result from the transformation of retained austenite into martensite, but also from the change in dislocation configuration and their contribution.

5. Misorientation angle distributions indicated that before the LCF, there is a large fraction of the retained austenite boundaries were located near 45 deg. Then, as a result of deformation, the contribution of these boundaries clearly decreased, and increases the low misorientation angles (boundaries between the martensite laths) and boundaries in the range of 55 to $60 \mathrm{deg}$ (boundaries between packets of ferrite/martensite laths) increased.

6. The hysteresis loop analysis showed that during cyclic deformation, dynamic deformation ageing occurred in the steel due to pinning of the dislocations by interstitial atoms present in the solid solution.

7. Analysis of the dislocation density in bainitic ferrite and austenite indicated that during cyclic deformation, the dislocation density in austenite increased with increasing amplitude, while the values in bainitic ferrite decreased, causing the formation of cell structures and subgrains.

\section{CONFLICT OF INTEREST}

The authors declare that they have no conflict of interest.

\section{OPEN ACCESS}

This article is licensed under a Creative Commons Attribution 4.0 International License, which permits use, sharing, adaptation, distribution and reproduction in any medium or format, as long as you give appropriate credit to the original author(s) and the source, provide a link to the Creative Commons licence, and indicate if changes were made. The images or other third party material in this article are included in the article's Creative Commons licence, unless indicated otherwise in a credit line to the material. If material is not included in the article's Creative Commons licence and your intended use is not permitted by statutory regulation or exceeds the permitted use, you will need to obtain permission directly from the copyright holder. To view a copy of this licence, visit http://creativecommons.org/licenses/by/4.0/.

\section{REFERENCES}

1. J. Herian and K. Aniolek: Arch. Mater. Sci. Eng., 2008, vol. 31, pp. 83-86.

2. E. Tasak, A. Ziewiec, and L. Tuz: Arch. Foundry Eng., 2014, vol. 14, pp. 115-20.

3. H.A. Aglan, Z.Y. Liu, M.F. Hassan, and M. Fateh: J. Mater. Process. Technol., 2004, vol. 151, pp. 268-74.

4. K.M. Lee and A.A. Polycarpou: Wear, 2005, vol. 259, pp. 391-99.

5. D.R. Johnson and W.T. Becker: J. Mater. Eng. Perform., 1993, vol. 2 , pp. 255-64.

6. G. Chen, G. Xu, H.S. Zurob, H. Hu, and X. Wan: Metall. Mater. Trans. A, 2019, vol. 50A, pp. 573-80.

7. A. Moser and P. Pointner: Transp. Res. Record., 1998, vol. 13, pp. $70-74$.

8. M. Zhou, G. Xu, J. Tian, H. Hu, and Q. Yuan: Metals, 2017, vol. 7, pp. 263-76

9. S.M. Hasan, M. Ghosh, D. Chakrabarti, and S.B. Singh: $J$. Mater. Sci. Eng. A, 2020, vol. 771, pp. 1385-90.

10. F.G. Caballero: Phase Transformations in Steels, Woodhead Publishing, Cambridge, 2012, pp. 436-67.

11. N.E. Tenaglia, J.M. Massone, R.E. Boeri, and J.G. Speer: Mater. Sci. Technol., 2020, vol. 36, pp. 690-98.

12. C. Zhang, S. Li, H. Fu, and Y. Lin: J. Mater. Res. Technol., 2020, vol. 9, pp. 4826-39.

13. C. Zhang, H. Fu, J. Lin, and Y. Lei: Trans. Indian Inst. Met., 2019, vol. 72, pp. 1231-44.

14. F.G. Caballero, M.J. Santofimia, C. García-Mateo, J. Chao, and C. García de Andrés: Mater. Des., 2009, vol. 30, pp. 2077-83.

15. S. Das, S. Sinha, A. Lodh, A.R. Chintha, M. Krugla, and A. Haldar: Mater. Sci. Technol., 2017, vol. 33, pp. 1026-37.

16. J. Liu, Y. Li, Y. Zhang, Y. Hu, L. Shi, H. Ding, W. Wang, F. Liu, S. Zhou, and T. Shi: Materials, 2020, vol. 13, pp. 4678-93.

17. E. Cadoni, H. Pham, and T. Iwamoto: EPJ Web Conf., 2015, vol. 94 , pp. 1-6.

18. M. Abareshi and E. Emadoddin: Mater. Des., 2011, vol. 32, pp. 5099-05.

19. T. Hilditch, H. Beladi, P. Hodgson, and N. Stanford: Mater. Sci. Eng. A, 2012, vol. 534, pp. 288-96.

20. Z.Z. Hu, M.L. Ma, Y.Q. Liu, and J.H. Liu: Int. J. Fatig., 1997, vol. 19, pp. 641-46.

21. R. Rementeria, L. Morales-Rivas, M. Kuntz, C. Garcia-Mateo, E. Kerscher, T. Sourmail, and F.G. Caballero: Mater. Sci. Eng. A, 2015, vol. 630, pp. 71-77.

22. Q. Zhou, L. Qian, J. Meng, and L. Zhao: Mater. Sci. Eng. A, 2021, vol. 820, pp. 141571-1583.

23. P.I. Christodoulou, A.T. Kermanidis, G.N. Haidemenopoulos, D. Krizan, and K. Polychronopoulou: Fatigue Fract. Eng. Mater. Struct., 2019, vol. 42, pp. 1085-99.

24. M.J. Hadianfard: Mater. Sci. Eng. A, 2009, vol. 499, pp. 493-99.

25. Z.Z. Hu, M. Ma, Y. Liu, and J. Liu: Int. J. Fatigue, 1997, vol. 19, pp. 641-46.

26. S. Ackermann, D. Kulawinski, S. Henkel, and H. Biermann: Int. J. Fatigue, 2014, vol. 67, pp. 123-33.

27. K.I. Sugimoto: Mater. Sci. Technol., 2009, vol. 25, pp. 1108-17.

28. S.M. Song, K. Sugimoto, S. Kandaka, A. Futamura, M. Kobayashi, and S. Masuda: Mater. Sci. Res. Int., 2003, vol. 9, pp. 223-29. 
29. D.J. Dyson and B. Holmes: J. Iron Steel Inst., 1970, vol. 208, pp. 469-74.

30. J.B. Nelson and D.P. Riley: Proc. Phys. Soc., 1945, vol. 57, pp. 486-95.

31. C. Garcia-Mateo, F.G. Caballero, C. Capdevila, and C.G.D. Andres: Scr. Mater., 2009, vol. 61, pp. 855-58.

32. S. Zajac, V. Schwinn, and K.H. Tacke: Mater. Sci. Forum, 2005, vols. 500-501, pp. 387-94.

33. E. Kozeschnik and H.K.D.H. Bhadeshia: Mater. Sci. Technol., 2008, vol. 24, pp. 343-47.

34. D. Delagnes, P. Lamesle, M.H. Mathonc, N. Mebarki, and C. Levaillant: J. Mater. Sci. Eng. A, 2005, vol. 394, pp. 435-44.

35. L.H. Ruan, K.M. Wu, J.A. Qiu, A.A. Shirzadi, and I.G. Rodionova: Met. Sci. Heat Treat., 2017, vol. 59, pp. 97-101.

36. M. Shah, S.K. Das, and S.G. Chowdhury: Metall. Mater. Trans. A, 2019, vol. 50A, pp. 2092-02.

37. A.F. Santacruz-Londono, O. Rios-Diez, J. Jiménez, C. Garcia-Mateo, and R. Aristizábal-Sierra: Metals, 2020, vol. 10, pp. $1-14$.

38. X.C. Xiong, B. Chen, M.X. Huang, J.F. Wang, and L. Wang: Scr. Mater., 2013, vol. 68, pp. 321-24.

39. A. Krolicka, K. Radwanski, A. Ambroziak, and A. Zak: $J$. Mater. Sci. Eng. A, 2019, vol. 768, pp. 1-11.

40. I.B. Timokhina, P.D. Hodgsonand, and E.V. Pereloma: Metall. Mater. Trans. A, 2004, vol. 35A, pp. 2331-41.

41. G.N. Haidemenopoulos and A.N. Vasilakos: Steel Res., 1996, vol. 67 , pp. $513-19$

42. E. Jimenez-Melero, N.H.V. Dijk, L. Zhao, J. Sietsma, S.E. Offerman, J.P. Wright, and S.V.D. Zwaag: Acta Mater., 2007, vol. 55 , pp. 6713-23.

43. O. Muransky, P. Hornak, P. Lukáasš, J. Zrnik, and P. Sittner: $J$. Achiev. Mater. Manuf. Eng., 2005, vol. 14, pp. 26-30.

44. E.V. Pereloma, A.A. Gazder, and I.B. Timokhina: Inf. Sci. Part $A$, 2017, vol. 18, pp. 3088-03.

45. R. Schnitzer, R. Radis, M. Nöhrer, M. Schober, R. Hochfellner, S. Zinner, E. Povoden-Karadeniz, E. Kozeschnik, and H. Leitner: Mater. Chem. Phys., 2010, vol. 122, pp. 138-45.

46. H.K. Bhadeshia and R.W. Honeycombe: Steels: Microstructure and Properties, 3rd ed., Elsevier, Amsterdam, 2006.

47. F.G. Caballero, M.K. Miller, A.J. Clarke, and C. Garcia-Mateo: Scr. Mater., 2010, vol. 63, pp. 442-44.

48. A. Kumar, A. Dutta, S.K. Makineni, M. Herbig, R.H. Petrov, and J. Sietsma: Mater. Sci. Eng. A, 2019, vol. 757, pp. 107-16.

49. H.K.D.H. Bhadeshia: Metal Sci., 1981, vol. 15, pp. 175-77.

50. J.H. Ryu, D.I. Kim, H.S. Kim, and H.K..DH. Bhadeshia: Scr. Mater., 2010, vol. 63, pp. 297-99.

51. W. Zhou, T. Hou, C. Zhang, L. Zhong, and K. Wu: Metals, 2018, vol. 8, pp. 907-18.

52. Q.G. Hao, S.W. Qin, Y. Liu, X.W. Zuo, N.L. Chen, W. Huang, and Y.H. Rong: Mater. Sci. Eng. A, 2016, vol. 662, pp. 16-25.

53. F.G. Caballero, C. Garcia-Mateo, and M. Miller: JOM, 2014, vol. 66 , pp. $747-55$.

54. A.M. Gola, M. Ghadamgahi, and S.W. Ooi: Wear, 2017, vol. 376 , pp. $975-82$.

55. H.F. Lan, L.X. Du, and R.D.K. Misra: Mater. Sci. Eng. A, 2014 vol. 611, pp. 194-200.

56. X. Long, F. Zhang, Z. Yang, and B. Lv: Mater. Sci. Eng. A, 2018, vol. 715 , pp. 10-16.

57. S. Ayenampudi, C. Celada-Casero, J. Sietsma, and M.J. Santofimia: Materialia, 2019, vol. 8, pp. 100492-503.

58. S. Khare, K. Lee, and H.K.D.H. Bhadeshia: Metall. Mater. Trans. A, 2010, vol. 41A, pp. 922-28.

59. S. Pashangeh, H.R. Karimi Zarchi, S.S. Ghasemi Banadkouki, and M.C. Somani: Metals, 2019, vol. 9, pp. 492-13.

60. A. Kumar, S.K. Makineni, A. Dutta, C. Goulas, M. Steenbergen, R.H. Petrov, and J. Sietsma: Mater. Sci. Eng. A, 2019, vol. 759 , pp. 210-23.

61. B. Avishan, C. Garcia-Mateo, L. Morales-Rivas, and F.G. Caballero: J. Mater. Sci., 2013, vol. 48, pp. 6121-32.

62. H.K.D.H. Bhadeshia and DV. Edmonds: Metal Sci., 1983, vol. 17 , pp. $411-19$

63. C.A.N. Lanzilloto and F.B. Pickering: Metal Sci., 1982, vol. 16, pp. 371-82.
64. C. Garcia-Mateo and F.G. Caballero: Mater. Trans., 2005, vol. 46, pp. 1839-46.

65. T. de Cock, J.P. Ferrer, C. Capdevila, F.G. Caballero, V. López, and C. García de Andrés: Scripta Mater., 2006, vol. 55, pp. 441-43.

66. H.A. Aglan and M. Fateh: J. Mech. Mater. Struct., 2007, vol. 2, pp. $335-46$

67. C. Garcia-Mateo and F.G. Caballero: SIJ Int., 2005, vol. 45, pp. $1736-40$

68. U.P. Singh, B. Roy, S. Jha, and S.K. Bhattacharyya: Mater. Sci. Technol., 2001, vol. 17, pp. 33-38.

69. H. Yokoyama, S. Mitao, S. Yamamoto, Y. Kataoka, and T. Sugiyama: NKK Tech. Rev., 2001, vol. 84, pp. 44-51.

70. J.C. Hell, M. Dehmas, S. Allain, J.M. Prado, A. Hazotte, and J.P. Chateau: ISIJ Int., 2011, vol. 51, pp. 1724-32.

71. J.P. Liu, Y.Q. Li, J.Y. Jin, Y.H. Zhang, F.S. Liu, R. Su, B. Narayanaswamy, and Q.Y. Zhou: Mater. Today Commun., 2020, vol. 25 , pp. 264-70.

72. O. Hajizad, A. Kumar, Z. Li, R.H. Petrov, J. Sietsma, and R. Dollevoet: Metals, 2019, vol. 9, pp. 778-97.

73. J.A. Ranzabal, I. Gutierrez, J.M. Rodriguez-Ibabe, and J.J. Urcola: Metall. Mater. Trans. A, 1997, vol. 28A, pp. 1143-56.

74. X.Y. Long, F.C. Zhang, and C.Y. Zhang: Mater. Sci. Eng. A, 2017, vol. 697, pp. 111-18.

75. T.B. Hilditch, I.B. Timokhina, L.T. Robertson, E.V. Pereloma, and P.D. Hodgson: Metall. Mater. Trans. A, 2009, vol. 40A, pp. $342-53$.

76. F.C. Zhang, X.Y. Long, J. Kang, D. Cao, and B. Lv: Mater. Des., 2016, vol. 94, pp. 1-8.

77. Q. Zhou, L.H. Qian, J.Y. Meng, L.J. Zhao, and F.C. Zhang: Mater. Des., 2015, vol. 85, pp. 487-96.

78. Q. Zhou, L. Qian, J. Meng, and L. Zhao: J. Mater. Sci. Eng. A, 2021, vol. 820, pp. 141571-583.

79. M.C. Marinelli, M. Balbi, and U. Krupp: Int. J. Fatigue, 2021, vol. 143 , pp. 106014-026.

80. F.C. Campbell: Elements of Metallurgy and Engineering Alloys, ASM International, Almere, 2008.

81. S. Sankaran, V. SubramanyaSarma, and K.A. Padmanabhan: Mater. Sci. Eng. A, 2003, vol. 345, pp. 328-35.

82. B. Adamczyk-Cieslak, M. Koralnik, R. Kuziak, T. Brynk, T. Zygmunt, and J. Mizera: Mater. Sci. Eng. A, 2019, vol. 747, pp. 144-53.

83. C. Gupta, J.K. Chakravartty, and S. Banerjee: Inter. J. Metall. Eng., 2013, vol. 2, pp. 142-148.

84. M. Koyama, T. Sawaguchi, and K. Tsuzaki: ISIJ Int., 2018, vol. 58 , pp. $1383-95$.

85. D. Tastemur and S. Gunduz: Mater. Res., 2018, vol. 21, pp. $564-74$

86. A. Sarkar, S.A. Maloy, and K.L. Murty: Mater. Sci. Eng. A, 2015, vol. 631, pp. 120-25.

87. A. Kipelova, R. Kaibyshev, V. Skorobogatykh, and I. Schenkova: J. Phys. Conf. Ser., 2010, vol. 240, pp. 121-25.

88. A. Kozlowska, B. Grzegorczyk, M. Morawiec, and A. Grajcar: Materials, 2019, vol. 12, pp. 4175-91.

89. G.A. Muhamed, S. Gunduz, M.A. Erden, and D. Tastemur: Metals, 2017, vol. 7, pp. 362-77.

90. A.K. Sachdev: Metall. Trans. A, 1982, vol. 13A, pp. 1793-97.

91. E.C. Bain and N.Y. Dunkirk: Trans. AIME, 1924, vol. 70, pp. 25-46.

92. G. Kurdjumow and G. Sachs: Z. Phys., 1930, vol. 64, pp. 325-43.

93. Z. Nishiyama: Sci. Rep. Tohoku Imp. Univ., 1934, vol. 23, pp. 637-38.

94. G. Wasserman: Arch Eisenhuttenwes, 1933, vol. 16, pp. 647-58.

95. A.B. Greninger and A.R. Troiano: JOM, 1949, vol. 1, pp. 590-98.

96. H. Beladi, Y. Adachi, I. Timokhina, and P. Hodgson: Scripta Mater., 2009, vol. 60, pp. 455-58.

97. S. Long, Y. Liang, Y. Jiang, Y. Liang, M. Yang, and Y. Yi: Mater. Sci. Eng. A, 2016, vol. 676, pp. 38-47.

98. S. Morito, X. Huang, T. Furuhara, T. Maki, and N. Hansen: Acta Mater., 2006, vol. 54, pp. 5323-31.

99. P.P. Suikkanen, C. Cayron, A.J. DeArdo, and L.P. Karjalainen: J. Mater. Sci. Technol., 2011, vol. 27, pp. 920-30.

100. A. Krolicka, K. Radwanski, R. Kuziak, T. Zygmunt, and A. Ambroziak: J Constr. Struct. Res., 2020, vol. 175, pp. 372-86. 
101. H. Beladi, G.S. Rohrer, A.D. Rollett, V. Tari, and P.D. Hodgson: Acta Mater., 2014, vol. 63, pp. 86-98.

102. A.F. Gourgues, H.M. Flower, and T.C. Lindle: Mater. Sci. Technol., 2000, vol. 16, pp. 26-40.

103. A. Glage, A. Weidner, T. Richter, P. Trubitz, and H. Biermann: Esomat, 2009, vol. 183, pp. 1-9.
104. Y. Wang, K. Zhang, Z. Guo, N. Chen, and Y. Rong: Mater. Sci. Eng. A, 2012, vol. 552, pp. 288-94.

Publisher's Note Springer Nature remains neutral with regard to jurisdictional claims in published maps and institutional affiliations. 